\title{
Methanotrophy potential versus methane supply by pore water diffusion in peatlands
}

\author{
E. R. C. Hornibrook, H. L. Bowes, A. Culbert, and A. V. Gallego-Sala \\ Bristol Biogeochemistry Research Centre, Department of Earth Sciences, University of Bristol, Wills Memorial Building, \\ Queens Road, Bristol BS8 1RJ, UK
}

Received: 4 March 2008 - Published in Biogeosciences Discuss.: 18 June 2008

Revised: 13 July 2009 - Accepted: 22 July 2009 - Published: 7 August 2009

\begin{abstract}
Low affinity methanotrophic bacteria consume a significant quantity of methane in wetland soils in the vicinity of plant roots and at the oxic-anoxic interface. Estimates of the efficiency of methanotrophy in peat soils vary widely in part because of differences in approaches employed to quantify methane cycling. High resolution profiles of dissolved methane abundance measured during the summer of 2003 were used to quantity rates of upward methane flux in four peatlands situated in Wales, UK. Aerobic incubations of peat from a minerotrophic and an ombrotrophic mire were used to determine depth distributions of kinetic parameters associated with methane oxidation. The capacity for methanotrophy in a $3 \mathrm{~cm}$ thick zone immediately beneath the depth of nil methane abundance in pore water was significantly greater than the rate of upward diffusion of methane in all four peatlands. Rates of methane diffusion in pore water at the minerotrophic peatlands were small $(<10 \%)$ compared to surface emissions during June to August. The proportions were notably greater in the ombrotrophic bogs because of their typically low methane emission rates. Methanotrophy appears to consume entirely methane transported by pore water diffusion in the four peatlands with the exception of 4 of the 33 gas profiles sampled. Flux rates to the atmosphere regardless are high because of gas transport through vascular plants, in particular, at the minerotrophic sites. Cumulative rainfall amount 3-days prior to sampling correlated well with the distance between the water table level and the depth of $0 \mu \mathrm{moll}^{-1}$ methane, indicating that precipitation events can impact methane distributions in pore water. Further work is needed to characterise the kinetics of methane oxidation spatially and temporally in different wetland types in order
\end{abstract}

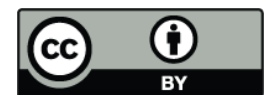

Correspondence to: E. R. C. Hornibrook (ed.hornibrook@bristol.ac.uk) to determine generalized relationships for methanotrophy in peatlands that can be incorporated into process-based models of methane cycling in peat soils.

\section{Introduction}

Alpha and gamma Proteobacteria belonging, respectively, to the Methylocystaceae and Methylococcaceae families are ubiquitous at oxic-anoxic interfaces in the Earth system where oxygen $\left(\mathrm{O}_{2}\right)$ is present and methane $\left(\mathrm{CH}_{4}\right)$ is transported in large quantities under the influence of concentration gradients or ebullition. These microorganisms, also known as Type I (gamma) and Type II (alpha) methanotrophs, serve as an efficient filter, removing $\mathrm{CH}_{4}$ that otherwise would enter the troposphere. Collectively low affinity methanotrophs in such environments annually consume a quantity of $\mathrm{CH}_{4}$ well in excess of the $\sim 600 \mathrm{Tg}$ that does enter the Earth's atmosphere from biological and geological sources (Fletcher et al., 2004).

The anoxic soils of natural wetlands are one of the main perennial sources of $\mathrm{CH}_{4}$ flux that help to maintain a low but significant quantity of this chemically and radiatively active organic gas in the Earth's highly oxidizing atmosphere. More than three decades of study of methanotrophs in wetlands and peatlands has yielded significant insights into their phylogeny, distribution, kinetics, and preferred growth conditions (e.g., Segers, 1998; Gutknecht, 2006; Chen et al., 2008). Methanotroph populations in the rhizosphere and with depth in peat soils have been mapped using molecular biology techniques, including PCR amplification of DNA extracts and hybridisation with specific phylogenetic 16S rRNA and functional gene primers (e.g., Krumholz et al., 1995; McDonald et al., 1996, 1999; Ritchie et al., 1997; Calhoun and

Published by Copernicus Publications on behalf of the European Geosciences Union. 
King, 1998; Edwards et al., 1998; Dedysh, 2002; Dedysh et al., 2001, 2003; Wartiainen et al., 2003; Miller et al., 2004), quantification of membrane phospholipids fatty acids (PLFA) (Krumholz et al., 1995; Sundh et al., 1995, 1997), and more recently stable isotope probing techniques involving ${ }^{13} \mathrm{C}$-labelling of PLFAs and nucleic acids (Morris et al. 2002; McDonald et al., 2005; Kreuzer-Martin, 2007; Chen et al., 2008). Both Type I and II methanotrophs occur in wetland soils, occupying oxic zones immediately adjacent to plant roots (King, 1994; 1996; Schipper and Reddy, 1996; Calhoun and King, 1998; van der Nat and Middelburg, 1998; Popp et al., 2000) and shallow zones within peat soils to which atmospheric $\mathrm{O}_{2}$ is able to diffuse under edaphic conditions and vegetation groundcover specific to particular types of wetlands (Krumholz et al., 1995; McDonald et al., 1996; Watson et al., 1997; Edwards et al., 1998; Beckman and Lloyd, 2001; Megonigal and Schlesinger, 2002).

The tolerance of methanotrophs to anoxia appears to vary (Roslev and King, 1996). Greatly diminished levels of methanotrophic activity have been reported in post-anoxia incubations of rhizome material (King, 1994) while sediment and peat from other wetlands upon return to $\mathrm{O}_{2}$-rich conditions have shown $\mathrm{CH}_{4}$ oxidation capacities ranging from moderately attenuated (e.g., King, 1990) to rapid and vigorous (Whalen and Reeburgh, 2000). Methane supply is most commonly cited as the factor limiting methanotrophy in peat soils (Boon and Lee, 1997; Megonigal and Schlesinger, 2002; Berestovskaya et al., 2005; Basiliko et al., 2007) although $\mathrm{O}_{2}$ availability also may restrict rates of $\mathrm{CH}_{4}$ uptake (King, 1990, 1994, 1996; Mikkelä et al., 1995; Beckman and Lloyd, 2001). Differences in the limiting factors between peatlands likely results from a combination of soil properties affecting gas exchange and heat transfer, the abundance and types of plants present, and water table depth, all of which impact the potential for $\mathrm{CH}_{4}$ oxidation and production (Kettunen et al., 1996; Kettunen, 2003). Water table level is a particularly critical parameter because it controls the thickness of the unsaturated zone, which when enlarged enhances the capacity for methanotrophy, but conversely diminishes $\mathrm{CH}_{4}$ production at shallow depths in vicinity of the rhizosphere where methanogens benefit from higher temperatures and an abundant supply of labile substrates from root exudation (Roulet et al., 1993; Sundh et al., 1994; Kettunen et al., 1999; Ström et al., 2005). Despite the presence of methanotrophy in this zone, $\mathrm{CH}_{4}$ flux from wetlands is significantly enhanced by gas exchange with the atmosphere through the aerenchyma of vascular plants (Shannon et al., 1996; Joabsson et al., 1999; Joabsson and Christensen, 2001; Oquist and Svensson, 2002; Ström and Christensen, 2007). In the absence of high temporal resolution measurements of $\mathrm{CH}_{4}$ flux capable of detecting sporadic ebullition events (Baird et al., 2004; Tokida et al., 2007a, b), estimates of $\mathrm{CH}_{4}$ emission from wetlands will be dominated by passive or active transport of $\mathrm{CH}_{4}$ through vascular aquatic plants when suitable plants are present.
Attempts to quantify the efficiency of methanotrophy in peat soils have yielded a wide range of estimates of $\mathrm{CH}_{4}$ consumption, in part, because of different methods employed and the limitations associated with specific approaches as discussed by Pearce and Clymo (2001). Le Mer and Roger (2001) concluded from a survey of literature that $~ 60$ to $90 \%$ of $\mathrm{CH}_{4}$ produced in wetland soils is oxidized by methanotrophs in the rhizosphere or shallow subsurface horizons; however, other estimates suggest a range of proportions, including $20-40 \%$ in general for natural wetlands (Whalen, 2005), 15 to $76 \%$ of potential diffusive $\mathrm{CH}_{4}$ flux seasonally and $\sim 43 \%$ annually of $\mathrm{CH}_{4}$ entering the oxic zone of a freshwater marsh (Roslev and King, 1996), 22\% for conversion of $\mathrm{CH}_{4}$ to $\mathrm{CO}_{2}$ during transport through $10 \mathrm{~cm}$ of acrotelm Sphagnum-rich peat (Pearce and Clymo, 2001), complete consumption within $20 \mathrm{~cm}$ of the water table in an undrained peatland (Roulet et al., 1993), $65 \pm 24 \%$ of $\mathrm{CH}_{4}$ entering the rhizosphere of Sagittaria lancifolia estimated by $\mathrm{CH}_{3} \mathrm{~F}$ inhibition and $79 \pm 20 \%$ by mass balance (Schipper and Reddy, 1996), $34.7 \pm 20.3 \%$ and $16.1 \pm 7.9 \%$ in the rhizosphere, respectively, of bulrush and reed wetlands (van der Nat and Middelburg, 1998), 55\% of upward diffusing $\mathrm{CH}_{4}$ in an Alaskan boreal peatland (Whalen and Reeburgh, 2000), $52 \pm 10 \%$ and $81 \pm 9 \%$ in two tidal freshwater wetland forests (Megonigal and Schlesinger, 2002), 0 to 34\% rhizosphere oxidation of $\mathrm{CH}_{4}$ in a Carex fen determined using ${ }^{13} \mathrm{C}$ mass balance (Popp et al., 1999), and 58 to $92 \%$ or $<20 \%$ in the same peatland depending upon whether $\mathrm{CH}_{4}$ consumption was quantified by subtracting in situ methane emission rates from $\mathrm{CH}_{4}$ production rates measured in the laboratory or in situ use of the $\mathrm{CH}_{3} \mathrm{~F}$ inhibitor technique (Popp et al., 2000). Much of the variability in estimates of $\mathrm{CH}_{4}$ oxidation efficiency appears to stem from differences in methodology. As noted by Popp et al. (2000), $\mathrm{CH}_{4}$ production rates determined in vitro likely lead to an overestimation of $\mathrm{CH}_{4}$ supply in peat soils, contributing to the calculation of anomalously high proportions of $\mathrm{CH}_{4}$ removal by methanotroph activity.

We investigated the balance between $\mathrm{CH}_{4}$ supply by pore water diffusion and the quantity of $\mathrm{CH}_{4}$ emitted to the atmosphere in four peatlands situated in Wales, UK during the summer of 2003 to determine the potential contribution of $\mathrm{CH}_{4}$ diffusion through pore water to total emissions and the degree to which methanotrophs may consume $\mathrm{CH}_{4}$ transported via pore water diffusion. Detailed ( $\mathrm{cm}$ scale resolution) in situ profiles of dissolved $\mathrm{CH}_{4}$ concentration were measured to estimate the supply of $\mathrm{CH}_{4}$ into the methanotrophic zone at the sites. Complete attenuation of $\mathrm{CH}_{4}$ transport via pore water diffusion was evident when the abundance of dissolved $\mathrm{CH}_{4}$ was $\sim 0 \mu \mathrm{moll}^{-1}$ within the saturated zone. We compared estimated rates of $\mathrm{CH}_{4}$ transport by pore water diffusion to total quantites of $\mathrm{CH}_{4}$ emitted to the atmosphere. We also used aerobic incubations of peat amended with $\mathrm{CH}_{4}$ to assess differences in $\mathrm{CH}_{4}$ uptake kinetics with depth and between two of the peatlands (a raised bog and an intermediate fen). In situ $\mathrm{CH}_{4}$ concentration data and 
Table 1. Sites descriptions (after Hornibrook and Bowes, 2007).

\begin{tabular}{|c|c|c|c|c|}
\hline Site & Wetland Type & Altitude & $\mathrm{pH}^{\mathrm{b}}$ & Dominant Vegetation \\
\hline Crymlyn Bog & intermediate fen & $\begin{array}{l}(\mathrm{m} \text { a.s.1. })^{\mathrm{a}} \\
9\end{array}$ & $5.5 \pm 0.5(n=20)$ & $\begin{array}{l}\text { Juncus squarrosum, Carex elata, } \\
\text { Eriophorum gracile, } \\
\text { Cladium mariscus, Sphagnum spp. }\end{array}$ \\
\hline Gors Lwyd & upland valley mire & 385 & $4.9 \pm 0.6(n=20)$ & $\begin{array}{l}\text { Erica tetralix, Eriophorum angustifolium, } \\
\text { Sphagnum spp. }\end{array}$ \\
\hline Blaen Fign & blanket bog & 504 & $4.2 \pm 0.3(n=20)$ & $\begin{array}{l}\text { J. squarrosus, Calluna vulgaris, } \\
\text { Trichophorum cespitosum, Molinia caerulea, } \\
\text { Sphagnum spp. }\end{array}$ \\
\hline Cors Caron & raised bog & 160 & $4.2 \pm 0.1(n=20)$ & $\begin{array}{l}\text { Rhyncospora alba, T. cespitosum, C. vulgaris, } \\
\text { Narcethium ossifragum, M. caerulea, Sphag- } \\
\text { num spp. }\end{array}$ \\
\hline
\end{tabular}

${ }^{\mathrm{a}} \mathrm{m}$ a.s.l. $=$ meters above sea level

b Mean pore water $\mathrm{pH} \pm$ standard deviation ( $1 \sigma ; n=\#$ of measurements) from 5 to $45 \mathrm{~cm}$ depth for May to August 2003.

the determined $\mu_{m}$ (maximum rates of $\mathrm{CH}_{4}$ oxidation) and $K_{s}$ (half saturation concentrations) values were employed to estimate the capacity for $\mathrm{CH}_{4}$ consumption in relation to the supply of $\mathrm{CH}_{4}$ by pore water diffusion. Finally, we also investigated relationships between cumulative rainfall in the period preceding pore water sampling and the distribution of $\mathrm{CH}_{4}$ with depth in the peatland soils to determine whether the timing of sampling impacted our results.

\section{Site characterisation}

\subsection{Peatland descriptions}

The locations of the four peatlands investigated in Wales, UK are shown in Fig. 1 and details about peatland elevation, pore water $\mathrm{pH}$, and dominant vegetation are provided in Table 1. Crymlyn Bog (51 $\left.38^{\circ} 11^{\prime \prime} \mathrm{N}, 03^{\circ} 53^{\prime} 18^{\prime \prime} \mathrm{W}\right)$ and Gors Lwyd $\left(52^{\circ} 15^{\prime} 44^{\prime \prime} \mathrm{N}, 03^{\circ} 34^{\prime} 44^{\prime \prime} \mathrm{W}\right)$ both receive water input from surrounding uplands via overland and subsurface flow and thus have slightly more alkaline pore water than Blaen Fign $\left(52^{\circ} 15^{\prime} 44^{\prime \prime} \mathrm{N}, 03^{\circ} 34^{\prime} 44^{\prime \prime} \mathrm{W}\right)$ and Cors Caron $\left(52^{\circ} 15^{\prime} 24^{\prime \prime} \mathrm{N}, 03^{\circ} 55^{\prime} 00^{\prime \prime} \mathrm{W}\right)$, which are ombrotrophic bogs. Sphagnum spp. were common at all sites; however, predictably the abundance of vascular plants was highest at the two minerotrophic peatlands Crymlyn Bog and Gors Lwyd. At each peatland, two adjacent stations ( $\sim 1 \mathrm{~m}$ apart) were chosen for installation of pore water equilibrators and ground collars to support flux chambers. At Crymlyn Bog and Blaen Fign the ground collars enclosed significantly different proportions of bryophytes and vascular plants with Sphagnum moss dominating at station 1 and sedge, grass and rush species at station 2 .

\subsection{Weather data}

Daily precipitation data for the period January to December 2003 collected at UK Meteorological Office Stations at Swyddffynnon, Cwmystwyth, Llangurig and Swansea Victoria Park (Fig. 1) were obtained from the British Atmospheric Data Centre (BADC) archive.

\section{Analytical Methods}

\subsection{Sample collection}

Pore water equilibrators and ground collars for flux chambers were installed at the sites several months prior to the onset of sampling which began in the spring of 2003. Measurements of in situ concentrations of pore water $\mathrm{CH}_{4}$ and $\mathrm{CH}_{4}$ flux rates to the atmosphere were performed between April and September 2003 at the four peatlands. One peatland was sampled each week yielding on average one monthly data set for each site during the growing season. Peat cores were collected in September 2005 for follow-up experiments investigating differences in methane oxidation kinetics with depth at Cors Caron and Crymlyn Bog.

\subsection{Methane flux}

Collection methods and $\mathrm{CH}_{4}$ flux data for all sites were reported previously in Bowes and Hornibrook (2006) and Hornibrook and Bowes (2007). Briefly, flux chambers and ground collars were constructed of polyvinyl chloride (PVC) and had a combined volume of either 11 or 151 . The chambers were sealed onto the collars using large neoprene rubber o-rings coated with silicon grease and then covered with opaque lids also fitted with greased o-rings. Air samples were collected via a 4-m length of 3-mm OD Tygon tube 


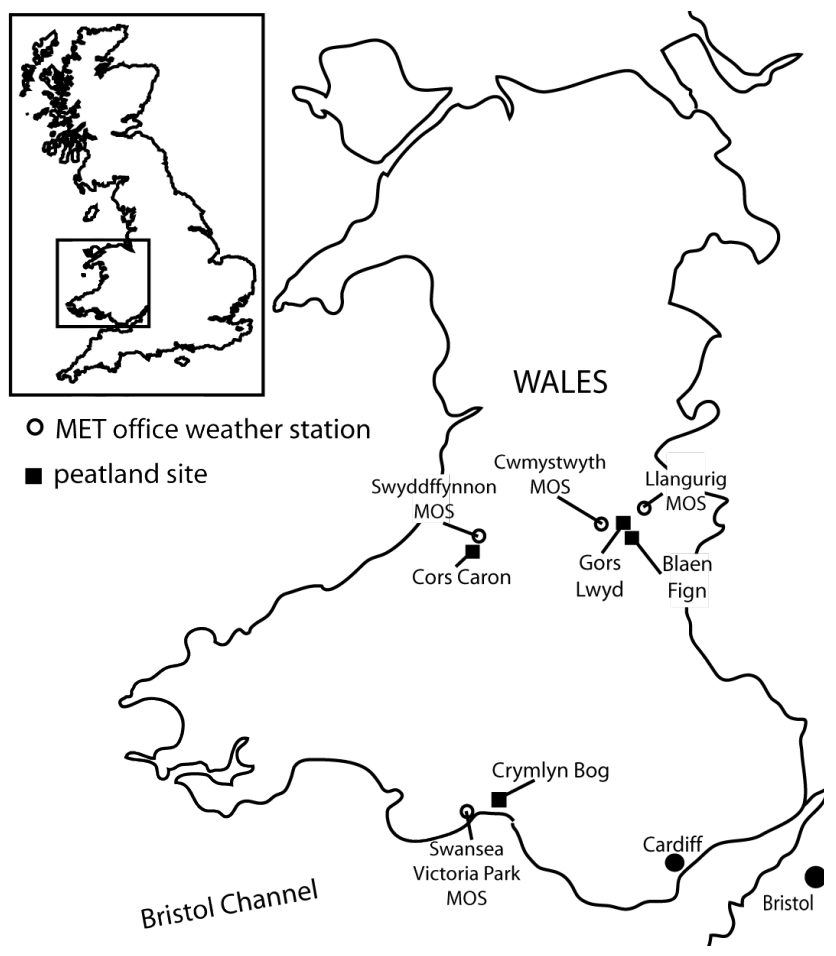

Fig. 1. Locations of peatland study sites and Met Office MIDAS Land Surface Observation Stations (MOS = Met Office Station) in Wales, UK. Details of the four peatlands are provided in Table 1, including map coordinates.

installed in the lid of each chamber. A second identical tube fitted in the lid was kept open during sampling to prevent subambient pressures from forming while air samples were collected. Each chamber contained a small battery operated fan to mix the headspace. Air samples for $\mathrm{CH}_{4}$ flux measurements were collected at 0 (chamber open), 5, 15 and $30 \mathrm{~min}$ in $60 \mathrm{ml}$ polypropylene syringes fitted with gas-tight valves. Independent flux determinations were conducted in triplicate for each station during each sampling trip.

\subsection{Pore water methane}

Collection methods and pore water $\mathrm{CH}_{4}$ data for Blaen Fign were reported previously in Bowes and Hornibrook (2006). The dissolved $\mathrm{CH}_{4}$ abundances for Crymlyn Bog, Gors Lwyd and Cors Caron are reported here for the first time. Briefly, the collection technique employed membraneexchange equilibrators constructed of PVC that were installed $\sim 15 \mathrm{~cm}$ from each ground collar. The equilibrators enabled sampling of pore water gases at closely spaced depth intervals $(2 \mathrm{~cm}$ resolution) for measurement of dissolved $\mathrm{CH}_{4}$ abundance. The design of Hesslein (1976) was modified to permit input and removal of de-ionised, de-gassed water after ground installation through 3-mm OD Tygon tubes connected to $1 \times 25 \times 0.5 \mathrm{~cm}(\mathrm{H} \times \mathrm{W} \times \mathrm{D})$ troughs that were sealed with a gas and ion permeable membrane filter $(0.2 \mu \mathrm{m}$ pore size; HT-200, Pall Life Sciences).

\subsection{Peat cores and properties}

Peat samples for porosity measurements and $\mathrm{CH}_{4}$ oxidation kinetic experiments were obtained from monoliths $\left(100 \mathrm{~cm}^{2}\right.$ cross-sectional area $\times 120 \mathrm{~cm}$ length $)$ collected using a Wardenaar peat corer (Eijelkamp, Netherlands). The peat was sectioned in the field into $1 \mathrm{dm}^{3}$ blocks, sealed in air tight bags and then packed in ice for transport to the laboratory.

Subsamples were extracted from the peat blocks in the laboratory to determine bulk density $\left(\rho_{\text {bulk }} ; \mathrm{g} \mathrm{cm}^{-3}\right)$ and porosity ( $\phi$; unitless). A specific volume of peat was dried to constant weight to determine $\rho_{\text {bulk }}$. Porosity $(\phi)$ was calculated from the equation:

$\phi=1-\frac{\rho_{\text {bulk }}}{\rho_{\text {particle }}}$

where $\rho_{\text {particle }}$ (particle density; $\mathrm{g} \mathrm{cm}^{-3}$ ) was assumed to be $1.4 \mathrm{~g} \mathrm{~cm}^{-3}$.

\subsection{Soil temperature and water table level}

Soil temperature was measured using an Omega Model HH41 handheld thermistor thermometer and a thermistor probe. The latter consisted of a nylon-coated type-K thermocouple encased within a $5-\mathrm{cm}$ long brass tube that had a wall thickness of $0.15 \mathrm{~mm}$. The lead wire of the thermocouple was passed through a 2-m long stainless steel tube enabling the protected thermocouple tip to be inserted to specific depths within the peat soil. A nylon plug was used to isolate thermally the thermocouple tip from the stainless steel tube.

The ambient water-table level at each peatland was measured relative to the moss surface in a $10 \times 10 \mathrm{~cm}$ hole that had been cut during a previous visit using the Wardenaar corer.

\subsection{Methane concentration analysis}

Methane concentrations in air samples collected for determining flux rates were analyzed using a Carlo Erba HRGC5300 gas chromatograph (GC) equipped with gassampling valve $\left(1 \mathrm{~cm}^{3}\right.$ sample loop), Porapak QS packed column $(3 \mathrm{~mm} \times 4 \mathrm{~m})$, and flame ionization detector (FID). The carrier gas was helium at $35 \mathrm{ml} \mathrm{min}^{-1}$, and FID support gases were hydrogen at $30 \mathrm{ml} \mathrm{min}^{-1}$ and zero air at $400 \mathrm{ml} \mathrm{min}^{-1}$. Samples were injected through $1 \mathrm{~cm}^{3}$ cartridges packed with magnesium perchlorate to remove $\mathrm{H}_{2} \mathrm{O}$. The relative precision of $\mathrm{CH}_{4}$ analysis in air samples typically was better than $\pm 2 \%$ based on replicate injections of BOC Specialty Gases alpha-gravimetric standards and actual samples. Flux rates were determined from the slope of linear regression equations fitted to the change in chamber $\mathrm{CH}_{4}$ concentration versus time. Rates were corrected for the areal coverage 
and volume of the chambers, and are expressed in units of $\mathrm{mg} \mathrm{CH} 4 \mathrm{~m}^{-2} \mathrm{~d}^{-1}$.

Methane was stripped from pore water into a headspace of helium using the method of McAullife (1971). The resulting gas samples were analyzed on the Carlo Erba HRGC5300 gas chromatograph (GC) under the same conditions used for analysis of $\mathrm{CH}_{4}$ in flux samples. Pore water concentrations of $\mathrm{CH}_{4}$ were corrected for differences in peat porosity and are expressed in units of $\mu \mathrm{mol} \mathrm{CH}_{4} \mathrm{I}^{-1}$.

\subsection{Methane oxidation kinetics}

Peat monoliths obtained from Cors Caron and Crymlyn Bog were subsampled in $5 \mathrm{~cm}$ slices $\left(\sim 0.5 \mathrm{dm}^{3}\right)$ centred on five depths $(5,12.5,20,27.5$ and $35 \mathrm{~cm})$. The material was slurried in a 1:1 ratio with autoclaved de-ionised water. Slurry from each depth was incubated in triplicate at $15^{\circ} \mathrm{C}$ in crimptop $35 \mathrm{ml}$ Wheaton serum vials containing a headspace of $\mathrm{CH}_{4}$ in zero air corresponding to initial dissolved $\mathrm{CH}_{4}$ concentrations $\left(S_{0}\right)$ of $\sim 10,25,50,100,250$ and $500 \mu \mathrm{M}$. An additional slurry sample for each depth was incubated in singular as a blank containing a headspace of air only to confirm the absence of net $\mathrm{CH}_{4}$ production. Within two hours of loading the vial headspace, the actual value of $S_{0}$ in each vial was determined by GC-FID analysis of $\mathrm{CH}_{4}$ in the headspace and Henry's Law. The rate of $\mathrm{CH}_{4}$ oxidation was determined subsequently from the decrease in headspace concentration of $\mathrm{CH}_{4}$ from time 0 (initial) to 24,48 and $72 \mathrm{~h}$. Gas samples were extracted using a $50 \mu \mathrm{l}$ Hamilton glass syringe fitted with a side-hole needle and gas-tight valve. Methane concentration was analyzed in triplicate using a Perkin Elmer Clarus 500 gas chromatogram fitted with an Elite PLOT Q mega-bore column $(30 \mathrm{~m} \times 0.53 \mathrm{~mm}$ diameter $)$ and FID. The carrier gas was helium at $45 \mathrm{ml} \mathrm{min}^{-1}$ and FID support gases were hydrogen at $35 \mathrm{ml} \mathrm{min}^{-1}$ and zero air at $450 \mathrm{ml} \mathrm{min}^{-1}$. The $\mathrm{CH}_{4}$ oxidation rates determined independently in triplicate for each of the six $S_{0}$ values (i.e., 18 rate measurements per depth) were used to determine the maximum specific rate of $\mathrm{CH}_{4}$ uptake $\left(\mu_{m}\right)$ and half saturation concentrations $\left(K_{s}\right)$ for each depth interval in the two peatlands. Oxygen presumably was not a limiting factor in our experiments given that the incubations were conducted in zero air and hence the single Monod expression was used to describe methanotroph consumption of $\mathrm{CH}_{4}$ in the vials:

$\mu=\frac{\mu_{m}\left[\mathrm{CH}_{4}\right]}{K_{s}+\left[\mathrm{CH}_{4}\right]}$

where $\mu$ is the rate of methanotrophy $\left(\mu \mathrm{moll}^{-1} \mathrm{~h}^{-1}\right), \mu_{m}$ is the maximum specific rate of $\mathrm{CH}_{4}$ uptake $\left(\mu\right.$ moll $\left.^{-1} \mathrm{~h}^{-1}\right)$, $\left[\mathrm{CH}_{4}\right]$ is the concentration of $\mathrm{CH}_{4}\left(\mu \mathrm{moll}{ }^{-1}\right)$ (i.e., $S_{0}$ values) and $K_{s}$ is the concentration of $\mathrm{CH}_{4}\left(\mu \mathrm{moll}^{-1}\right)$ required to attain half the maximum rate of $\mathrm{CH}_{4}$ uptake. Equation (2) was fitted to the $\mathrm{CH}_{4}$ oxidation rate and $S_{0}$ data using nonlinear regression software (Prism v4.0, GraphPad Software, San Diego, CA, USA).

\subsection{Diffusion rates for $\mathrm{CH}_{4}$ in pore water}

The rate of upward $\mathrm{CH}_{4}$ diffusion in pore water at each peatland was determined using Ficks 1st Law:

$J=D_{S}\left(\frac{d\left[\mathrm{CH}_{4}\right]}{d z}\right)$

where $J$ is the flux rate $\left(\mu \mathrm{mol} \mathrm{cm} \mathrm{s}^{-1}\right), D_{s}$ is the temperature and porosity corrected diffusion coefficient for $\mathrm{CH}_{4}$ in water $\left(\mathrm{cm}^{2} \mathrm{~s}^{-1}\right)$ and $d\left[\mathrm{CH}_{4}\right] / d z$ is the $\mathrm{CH}_{4}$ concentration gradient $\left(\mu \mathrm{mol} \mathrm{cm}{ }^{-3} \mathrm{~cm}^{-1}\right)$ with depth $(\mathrm{cm})$ in peat soils. Ficks 1st law was used because the amount of time required to sample an equilibrator profile $(\sim 1 \mathrm{~h})$ is small and hence the measured gradients can be treated as being effectively steady state. Final values of $J$ are expressed in $\mathrm{mg} \mathrm{CH}_{4} \mathrm{~m}^{-2} \mathrm{~d}^{-1}$ to facilitate comparison with $\mathrm{CH}_{4}$ fluxes to the atmosphere measured using static chambers. The temperature dependency of $D_{S}$ was based upon polynomial regression of diffusion coefficients for $\mathrm{CH}_{4}$ in water in the range 0 to $35^{\circ} \mathrm{C}$ (83rd Edition of the Handbook of Physics and Chemistry) which yielded the relationship:

$D=8.889 \times 10^{-11} T^{3}-1.714 \times 10^{-9} T^{2}$

$+3.721 \times 10^{-7} T+8.771 \times 10^{-6}$

A value of $D$ was calculated for each $\mathrm{CH}_{4}$ profile based upon the mean soil temperature measured in situ across the depth interval for which pore water $\mathrm{CH}_{4}$ concentration data were linearly regressed to determine $d\left[\mathrm{CH}_{4}\right] / d z$. Values of $D$ were porosity corrected using Eq. (5) from Lerman (1979):

$D_{S}=D \phi^{2}$

where $\phi$ is porosity (unitless). For each pore water data set, an average value of $\phi$ was calculated from in situ porosity measurements collected across the $d\left[\mathrm{CH}_{4}\right] / d z$ depth interval.

\section{Results}

\subsection{Daily precipitation and timing of sampling}

The timing of sample collection at Crymlyn Bog, Cors Caron, Blaen Fign and Gors Lwyd is shown in Fig. 2 in relation to total daily precipitation measured at UK Meteorological Office Stations (MOSs) situated near the peatlands. Swansea Victoria Park (Fig. 2a) and Swyddffynnon (Fig. 2b) MOSs are located immediately adjacent to Crymlyn Bog and Cors Caron, respectively, providing accurate daily precipitation records for each site. There are no active MOSs in close proximity to either Blaen Fign or Gors Lwyd because of their remote locations in the Elan Valley. Consequently daily precipitation records from the Cwmystwyth and Llangurig MOSs, which geographically bracket the peatland sites, have been used (Fig. 2c and d) 


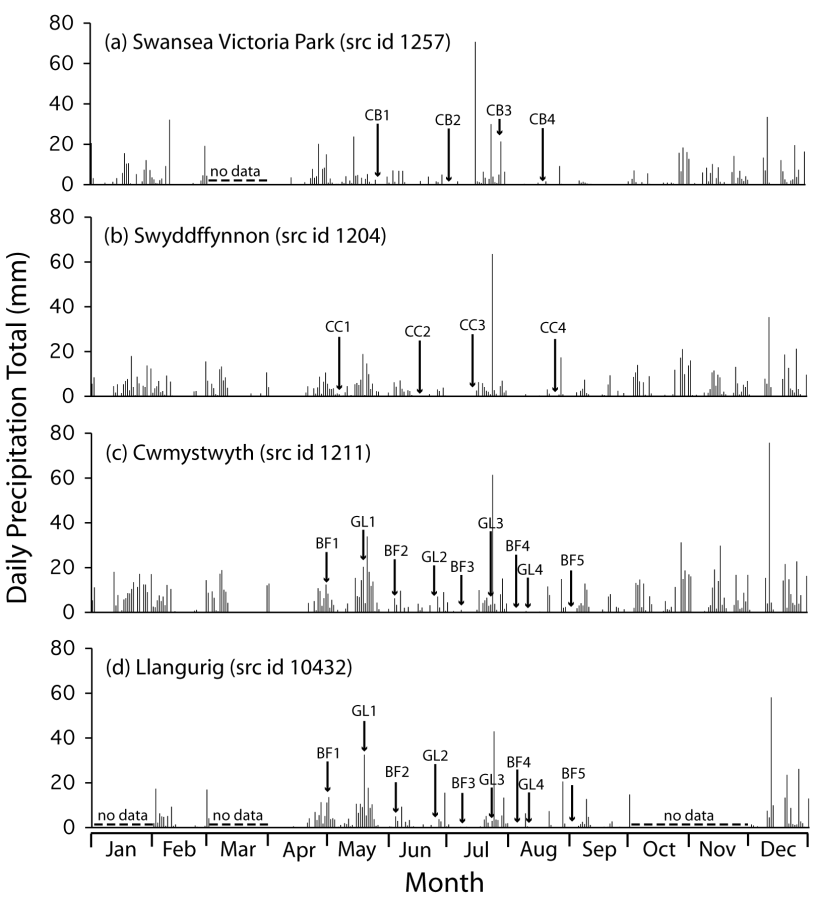

Fig. 2. Sample collection dates at Crymlyn Bog (CB1 27.5.03; CB2 2.7.03; CB3 28.7.03; CB4 19.8.03), Cors Caron (CC1 7.5.03; CC2 17.6.03; CC3 14.7.03; CC4 25.8.03), Blaen Fign (BF1 30.4.03; BF2 4.6.03; BF3 8.7.03; BF4 5.8.03; BF5 2.9.03), and Gors Lwyd (GL1 19.5.03; GL2 24.6.03; GL3 23.7.03; GL4 11.8.03) and daily precipitation amounts for 2003 from Met Office MIDAS Land Surface Observation Stations at Swansea Victoria Park (src id 1257; 51 $36^{\prime} 43^{\prime \prime} \mathrm{N}, 03^{\circ} 57^{\prime} 43^{\prime \prime} \mathrm{W} ; 8 \mathrm{~m}$ a.s.1.), Swyddffynnon (src id $1204 ; 52^{\circ} 16^{\prime} 19^{\prime \prime} \mathrm{N}, 03^{\circ} 54^{\prime} 54^{\prime \prime} \mathrm{W} ; 168 \mathrm{~m}$ a.s.l.), Cwmystwyth (src id 1211; $52^{\circ} 21^{\prime} 29^{\prime \prime} \mathrm{N}, 03^{\circ} 48^{\prime} 07^{\prime \prime} \mathrm{W} ; 301 \mathrm{~m}$ a.s.l.), and Llangurig (src id $10432 ; 52^{\circ} 24^{\prime} 14^{\prime \prime} \mathrm{N}, 03^{\circ} 36^{\prime} 22^{\prime \prime} \mathrm{W} ; 273$ m a.s.1.).

\subsection{Pore water $\mathrm{CH}_{4}$}

Pore water profiles of dissolved $\mathrm{CH}_{4}$, ambient water table levels, linear regression curves from which values of $d\left[\mathrm{CH}_{4}\right] / d z$ were obtained, and the $3 \mathrm{~cm}$ thick zone immediately beneath depth $\left[\mathrm{CH}_{4}\right]_{0}$ in soils at the four peatlands during the summer of 2003 are shown in Figs. 3 to 6. Pore water $\mathrm{CH}_{4}$ concentration profiles at all sites exhibited a similar shape although the size of the zone beneath the water table in which dissolved $\mathrm{CH}_{4}$ abundance was below the detection limit of our analysis method varied widely between peatlands and sampling months at individual sites. The potential impact of the magnitude and timing of rainfall events on the size of the zone where $\left[\mathrm{CH}_{4}\right]<0 \mu \mathrm{moll}^{-1}$ will be explored further in Sect. 5.1.

\section{3 $\mathrm{CH}_{4}$ oxidation kinetics}

Maximum potential rates of $\mathrm{CH}_{4}$ oxidation $\left(\mu_{m}\right)$ and half saturation concentrations $\left(K_{S}\right)$ determined from incubations

$$
\mathrm{CH}_{4}(\mu \mathrm{mol} \mathrm{I}-1)
$$
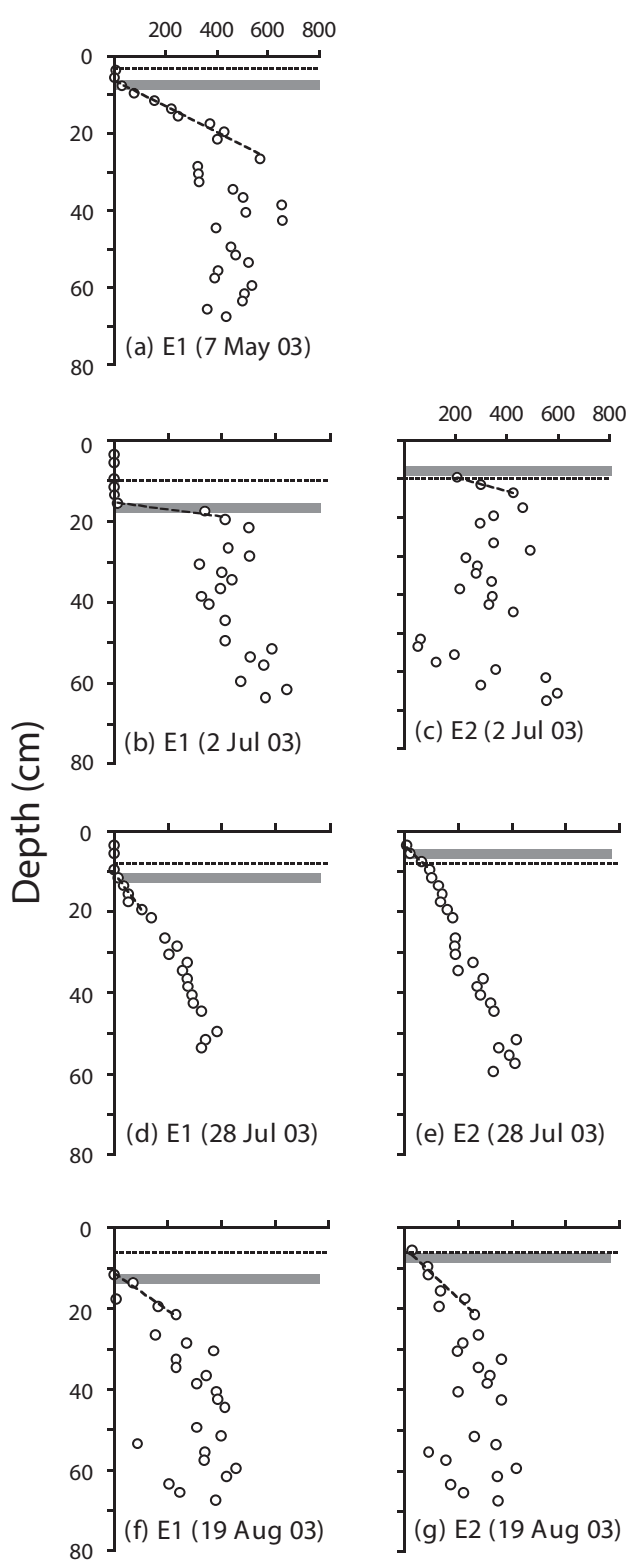

Fig. 3. Pore water profiles of dissolved $\mathrm{CH}_{4}$ measured at Crymlyn Bog during the summer of 2003 from pore water equilibrators E1 and E2. Water-table level in each panel is indicated by a dotted horizontal line and inverted filled triangle. The dashed line through shallow $\mathrm{CH}_{4}$ values trending to zero concentration is a regression line fitted to the data to determine the gradient $\mathrm{d}\left[\mathrm{CH}_{4}\right] / \mathrm{dz}$, which was used to calculate rates of $\mathrm{CH}_{4}$ flux into the methanotrophic zone and the depth at which $\left[\mathrm{CH}_{4}\right]=0 \mu \mathrm{moll}^{-1}$ (i.e., the y-intercept denoted as $\left.\left[\mathrm{CH}_{4}\right]_{0}\right)$. The gray horizontal bar delineates a $3 \mathrm{~cm}$ thick zone immediately beneath depth $\left[\mathrm{CH}_{4}\right]_{0}$ in which potential rates of $\mathrm{CH}_{4}$ oxidation were calculated based upon experimentally determined kinetic parameters (see Sect. 4.3) and in situ dissolved $\mathrm{CH}_{4}$ concentrations. If gaps existed in pore water $\left[\mathrm{CH}_{4}\right]$ data, missing values were interpolated between adjacent $\mathrm{CH}_{4}$ concentrations, including when necessary the point $\left[\mathrm{CH}_{4}\right]_{0}=0 \mu \mathrm{moll}^{-1}$. 
Table 2. Maximum $\mathrm{CH}_{4}$ oxidation rates $\left(\mu_{m}\right)$ and half saturation constants $\left(K_{S}\right)$

\begin{tabular}{|c|c|c|c|c|c|}
\hline \multirow[b]{2}{*}{ Site } & \multirow{2}{*}{$\begin{array}{l}\text { Depth } \\
\text { Interval } \\
\mathrm{cm}\end{array}$} & \multicolumn{2}{|c|}{$S_{0}=10$ to $500 \mu \mathrm{moll}^{-1}$} & \multicolumn{2}{|c|}{$S_{0}=10$ to $100 \mu \mathrm{moll}^{-1}$} \\
\hline & & $\begin{array}{l}\mu_{m} \pm \mathrm{SE}^{\mathrm{a}} \\
\mu \mathrm{mol} 1^{-1} \mathrm{~h}^{-1}\end{array}$ & $\begin{array}{l}K_{s} \pm \mathrm{SE}^{\mathrm{a}} \\
\mu \mathrm{mol} 1^{-1}\end{array}$ & $\begin{array}{l}\mu_{m} \pm \mathrm{SE}^{\mathrm{a}} \\
\mu \mathrm{mol} 1^{-1} \mathrm{~h}^{-1}\end{array}$ & $\begin{array}{l}K_{S} \pm \mathrm{SE}^{\mathrm{a}} \\
\mu \mathrm{mol} 1^{-1}\end{array}$ \\
\hline \multirow[t]{5}{*}{ Crymlyn Bog } & 2.5 to 7.5 & $26 \pm 8$ & $231 \pm 116$ & $4.1 \pm 0.9$ & $8.3 \pm 8.0$ \\
\hline & 10 to 15 & $70 \pm 78$ & $903 \pm 1329$ & $\mathrm{dnc}^{\mathrm{b}}$ & $\mathrm{dnc}^{\mathrm{b}}$ \\
\hline & 17.5 to 22.5 & $40 \pm 19$ & $198 \pm 187$ & $3.3 \pm 1.9$ & $10.2 \pm 20.1$ \\
\hline & 25 to 30 & $8 \pm 2$ & $137 \pm 93$ & $1.8 \pm 1.8$ & $11.5 \pm 40.0$ \\
\hline & 32.5 to 37.5 & $\mathrm{dnc}^{\mathrm{b}}$ & $\mathrm{dnc}^{\mathrm{b}}$ & $\mathrm{dnc}^{\mathrm{b}}$ & $\mathrm{dnc}^{\mathrm{b}}$ \\
\hline \multirow[t]{5}{*}{ Cors Caron } & 2.5 to 7.5 & $24 \pm 3$ & $83 \pm 30$ & $21.1 \pm 6.4$ & $68.1 \pm 38.0$ \\
\hline & 10 to 15 & $103 \pm 97$ & $881 \pm 1091$ & $15.6 \pm 3.9$ & $45.8 \pm 25.1$ \\
\hline & 17.5 to 22.5 & $106 \pm 88$ & $956 \pm 1026$ & $14.5 \pm 4.0$ & $51.2 \pm 28.6$ \\
\hline & 25 to 30 & $43 \pm 17$ & $353 \pm 208$ & $10.5 \pm 1.9$ & $42.6 \pm 17.1$ \\
\hline & 32.5 to 37.5 & $25 \pm 8$ & $54 \pm 49$ & $\mathrm{dnc}^{\mathrm{b}}$ & $d n c^{b}$ \\
\hline
\end{tabular}

a $\mathrm{SE}=$ standard error

$\mathrm{b}$ dnc $=$ did not converge

of slurried peat are presented in Table 2. The methanotrophy rate and $S_{0}$ data were fitted twice with Eq. (2): once using all data $\left(S_{0}=10\right.$ to $\left.500 \mu \mathrm{moll}^{-1}\right)$ and a second time excluding the $S_{0}=250$ and $500 \mu \mathrm{moll}^{-1}$ measurements (i.e., using $S_{0}=10$ to $100 \mu \mathrm{moll}^{-1}$ ). The $\mu_{m}$ and $K_{s}$ values determined using all data are anomalous, in particular, the $K_{s}$ values which exceed all half saturation constants reported to date for low affinity methanotropy by 1 to 2 orders of magnitude. The $\mu_{m}$ values are similarly high with values from the two samples in the depth interval 10 to $22.5 \mathrm{~cm}$ at Cors Caron being $\sim 10$ times greater than any maximum potential rates for $\mathrm{CH}_{4}$ oxidation in freshwater environments reported to date. These anomalous values appear to result from the disproportionate effects of high $\mathrm{CH}_{4}$ oxidation rates determined from the small number of incubations having $S_{0}=250$ and $500 \mu \mathrm{moll}^{-1}$. Such concentrations of $\mathrm{CH}_{4}$ are uncommon in situ at the oxic-anoxic interface in peatlands and consequently, Eq. (2) was fit to the data a second time excluding $\mathrm{CH}_{4}$ oxidation rates from the two highest values of $S_{0}$ (250 and $500 \mu \mathrm{moll}^{-1}$ ). The resulting $\mu_{m}$ and $K_{s}$ values are consistent with kinetic parameters typically associated with low affinity methanotrophy in aerobic environments. The half saturation concentrations are still amongst the highest reported to date; however, they are similar to published values of $K_{s}$ for peat soils, which tend to be large relative to other methanotrophic environments (Segers, 1998).

Notably the $S_{0}=10$ to $100 \mu \mathrm{moll}^{-1}$ set of depth profiles of $\mu_{m}$ and $K_{s}$ samples do not show maxima at depths near the lower limit of water table fluctuations (which are present in the $\mu_{m}$ and $K_{s}$ values from analysis of the complete data set). Instead $\mu_{m}$ values decrease steadily with increasing depth. The large standard errors associated with the $K_{s}$ parameter preclude any broad generalisation about trends with depth of the half saturation constant in soils at either site.

\subsection{Rates of $\mathrm{CH}_{4}$ flux and consumption}

A summary of rates of internal and external $\mathrm{CH}_{4}$ fluxes (all sites) and subsurface methanotrophy potentials (Crymlyn Bog and Cors Caron only) are presented in Table 3. Rates of upward $\mathrm{CH}_{4}$ flux into the methanotrophic zone were determined according to the method described in Sect. 3.8 and then scaled to a cross-sectional area of $1 \mathrm{~m}^{2}$. The majority of $\mathrm{CH}_{4}$ fluxes by pore water diffusion had a magnitude $<10$ $\mathrm{mg} \mathrm{m}^{-2} \mathrm{~d}^{-1}$. The concentration of dissolved $\mathrm{CH}_{4}$ at the water table surface was $>0 \mu \mathrm{moll}^{-1}$ in only 5 of the 33 pore water $\mathrm{CH}_{4}$ profiles (Figs. 3c, e, g, 6c and f), suggesting that diffusion of $\mathrm{CH}_{4}$ across the air-water interface contributes little to atmospheric emissions of $\mathrm{CH}_{4}$ at these sites. Methane escaping from the water surface within the peat profile must still transit pore spaces and methanotroph populations in the unsaturated zone before reaching the atmosphere.

In all cases the rate of upward $\mathrm{CH}_{4}$ flux was less than the capacity for $\mathrm{CH}_{4}$ oxidation determined in a $3 \mathrm{~cm}$ thick zone immediately below the depth at which $\left[\mathrm{CH}_{4}\right]=0 \mu \mathrm{moll}^{-1}$ (Table 3). The potential for methanotrophy in the $3 \mathrm{~cm}$ thick zone was estimated by integrating rates of $\mathrm{CH}_{4}$ oxidation calculated by substituting values of $\mu_{m}$ and $K_{s}$, and in situ dissolved $\mathrm{CH}_{4}$ concentrations into Eq. (2). A peat interval of $3 \mathrm{~cm}$ downward from the point $\left[\mathrm{CH}_{4}\right]_{0}$ was chosen because (i) depths above the point $\left[\mathrm{CH}_{4}\right]_{0}$ yield methanotrophy rates ( $\mu$ ) equal to zero using Eq. (2), (ii) $3 \mathrm{~cm}$ was the minimum depth reported by Beckmann and Lloyd (2001) for penetration of $\mathrm{O}_{2}$ by diffusion into a Scottish peat soil, and (iii) our aim was to provide a conservative estimate of $\mathrm{CH}_{4}$ oxidation potentials based upon the kinetic parameters determined in laboratory incubations. For example, the values of potential capacity for $\mathrm{CH}_{4}$ uptake noted in Table $3\left(\mathrm{mg} \mathrm{CH}_{4} \mathrm{~m}^{-2} \mathrm{~d}^{-1}\right)$ are $\sim 3$ orders of magnitude smaller than integrated oxidation rates reported by Sundh et al. (1994) for boreal peatlands in 
Table 3. Internal and external methane fluxes and subsurface oxidation potentials.

\begin{tabular}{|c|c|c|c|c|c|c|}
\hline & & Station $1^{\mathrm{a}}$ & & & Station $2^{\mathrm{a}}$ & \\
\hline Site \& Date & $\begin{array}{l}\mathrm{CH}_{4} \text { flux into } \\
\text { Oxidation zone }\end{array}$ & $\begin{array}{l}\text { Potential } \mathrm{CH}_{4} \\
\text { Oxidation rate }\end{array}$ & $\begin{array}{l}\text { Surface } \\
\mathrm{CH}_{4} \text { Flux }^{\mathrm{d}}\end{array}$ & $\begin{array}{l}\mathrm{CH}_{4} \text { flux into } \\
\text { Oxidation zone }\end{array}$ & $\begin{array}{l}\text { Potential } \mathrm{CH}_{4} \\
\text { Oxidation rate }\end{array}$ & $\begin{array}{l}\text { Surface } \\
\mathrm{CH}_{4} \text { Flux }^{\mathrm{d}}\end{array}$ \\
\hline Crymlyn Bog & $\mathrm{mgCH}_{4} \mathrm{~m}^{-2} \mathrm{~d}^{-1}$ & $\mathrm{mgCH}_{4} \mathrm{~m}^{-2} \mathrm{~d}^{-1}$ & $\mathrm{mgCH}_{4} \mathrm{~m}^{-2} \mathrm{~d}^{-1}$ & $\mathrm{mgCH}_{4} \mathrm{~m}^{-2} \mathrm{~d}^{-1}$ & $\mathrm{mgCH}_{4} \mathrm{~m}^{-2} \mathrm{~d}^{-1}$ & $\mathrm{mgCH}_{4} \mathrm{~m}^{-2} \mathrm{~d}^{-1}$ \\
\hline 27-May-03 & $4.4 \pm 0.2$ & 35.2 & $26.3 \pm 16.4$ & & & $156 \pm 68$ \\
\hline 2-Jul-03 & $15.8 \pm 5.7$ & 30.7 & $42.6 \pm 22.6$ & $9.3 \pm 0.9^{\mathrm{e}}$ & 9.6 & $130 \pm 16(3)$ \\
\hline 28-Jul-03 & $1.6 \pm 0.1$ & 26.7 & $52.4 \pm 17.6$ & $2.4 \pm 0.3^{\mathrm{e}}$ & 20.8 & $279 \pm 27$ (3) \\
\hline 19-Aug-03 & $3.4 \pm 0.4$ & 18.8 & $116 \pm 62(3)$ & $2.4 \pm 0.3^{\mathrm{e}}$ & 30.0 & $287 \pm 116(3)$ \\
\hline \multicolumn{7}{|l|}{ Gors Lwyd } \\
\hline 19-Мay-03 & $2.9 \pm 0.3$ & - & $4.7 \pm 2.8(2)$ & $4.4 \pm 0.3$ & - & $2.3 \pm 1.5(2)$ \\
\hline 24-Jun-03 & $17.6 \pm 2.8$ & $\begin{array}{l}- \\
- \\
-\end{array}$ & - & $13.7 \pm 0.0$ & $\begin{array}{l}- \\
- \\
-\end{array}$ & $33.6 \pm 9.8(3)$ \\
\hline 23-Jul-03 & $17.5 \pm 0.0$ & - & $461 \pm 140(2)$ & $6.1 \pm 1.1$ & - & $168(1)$ \\
\hline 11-Aug-03 & $7.7 \pm 1.2$ & - & $872(1)$ & $5.4 \pm 2.5$ & - & $386 \pm 251$ (3) \\
\hline \multicolumn{6}{|l|}{ Blaen Fign } & $36.4 \pm 27.5(3)$ \\
\hline 4-Jun- 03 & $2.5 \pm 0.3$ & - & $17.9 \pm 2.4$ (3) & $6.1 \pm 1.1$ & - & $187 \pm 30(3)$ \\
\hline 8-Jul-03 & $3.9 \pm 1.0$ & - & $7.3 \pm 5.2(3)$ & $3.4 \pm 0.1$ & - & $73.5 \pm 77.8(3)$ \\
\hline 5-Aug-03 & $1.3 \pm 0.4$ & - & $10.5 \pm 2.2(3)$ & $3.1 \pm 0.0$ & - & $85.4 \pm 58.6(3)$ \\
\hline 2-Sep-03 & $2.0 \pm 0.3$ & - & $21.4 \pm 12.5$ & $3.6 \pm 0.4$ & - & $99.4 \pm 16.7$ (3) \\
\hline \multicolumn{7}{|l|}{ Cors Caron } \\
\hline 7-May-03 & $5.3 \pm 1.3$ & 59.3 & $4.8 \pm 2.4$ (3) & $8.1 \pm 0.8$ & 63.4 & $0.3 \pm 0.1(2)$ \\
\hline 17-Jun-03 & $1.5 \pm 0.1^{\mathrm{e}}$ & 35.6 & $8.8 \pm 3.2(3)$ & $1.4 \pm 0.0$ & 34.5 & $12.2 \pm 2.4(3)$ \\
\hline 14-Jul-03 & $2.3 \pm 0.6$ & 15.1 & $11.8 \pm 4.2(3)$ & $1.3 \pm 0.4^{\mathrm{e}}$ & 5.3 & $10.1 \pm 3.6(3)$ \\
\hline 25-Aug-03 & $2.0 \pm 0.2$ & 34.9 & $18.2 \pm 7.7(3)$ & $2.7 \pm 0.5$ & 32.3 & $12.8 \pm 4.3(3)$ \\
\hline
\end{tabular}

a The ground surface at station 1 contained a greater abundance of Sphagnum and fewer vascular species than station 2 at Crymlyn Bog and Blaen Fign.

${ }^{\mathrm{b}}$ Rates of internal $\mathrm{CH}_{4}$ flux into the zone of methanotrophy based upon Ficks $1^{\text {st }}$ law (Eq. (2)) and linear regression analysis of pore water $\mathrm{CH}_{4}$ data shown in Fig. 2 to 5.

${ }^{c}$ Potential rate of $\mathrm{CH}_{4}$ oxidation in a $3 \mathrm{~cm}$ thick zone below the depth at which $\left[\mathrm{CH}_{4}\right]=0 \mu$ mol $1^{-1}$ defined by the y-intercept of linear regression analysis of pore water $\mathrm{CH}_{4}$ concentration data in Figures 2 to 5 . The total potential rate of $\mathrm{CH}_{4}$ oxidation in the $3 \mathrm{~cm}$ thick zone is based upon actual $\mathrm{CH}_{4}$ concentrations measured in peat soils and the depth distribution of $\mu_{m}$ and $K_{s}$ parameters determined experimentally for Crymlyn Bog and Cors Caron (Table 2).

$\mathrm{d}$ Total diffusive $\mathrm{CH}_{4}$ flux to the atmosphere measured using closed dynamic chambers and reported previously in Bowes and Hornibrook (2006) and Hornibrook and Bowes (2007). The number of chamber deployments is shown in brackets (i.e., $n=1,2$ or 3 ). Where $n=3$ the error shown is a standard deviation and for $n=2$ the \pm value is the range. The number of flux measurements omitted because of evidence of natural or induced ebullition was: Crymlyn Bog 0 of 24, Gors Lwyd 10 of 24, Blaen Fign 0 of 30, and Cors Caron 1 of 24.

e The concentration of dissolved $\mathrm{CH}_{4}$ in pore water at the subsurface air-water interface was $>0 \mu \mathrm{mol}^{-1}$ on these days.

Sweden that were based upon a 0 to $60 \mathrm{~cm}$ depth interval (3.0 to $22.1 \mathrm{~g} \mathrm{CH}_{4} \mathrm{~m}^{-2} \mathrm{~d}^{-1}$ ). Integration over large depth intervals is accurate when a double Monod expression incorporating availability of $\mathrm{O}_{2}$ can be employed; however, we did not measure either in situ concentrations of pore water $\mathrm{O}_{2}$ or kinetic parameters associated with $\mathrm{O}_{2}$ consumption, hence we opted for the conservative approach of applying the determined $\mu_{m}$ and $K_{S}$ values to a small depth interval in which $\mathrm{O}_{2}$ was likely to be available.
The integrated methanotrophy potential rates were scaled to an area of $1 \mathrm{~m}^{2}$ to facilitate comparison with pore water $\mathrm{CH}_{4}$ diffusive fluxes and directly measured rates of $\mathrm{CH}_{4}$ emission to the atmosphere. The latter also are shown in Table 3 and have been reported previously in Bowes and Hornibrook (2006) and Hornibrook and Bowes (2007). The $\mathrm{CH}_{4}$ fluxes to the atmosphere are due only to steady-state diffusion processes (i.e., pore water or plant-mediated transport). Chamber measurements that exhibited erratic pulses 


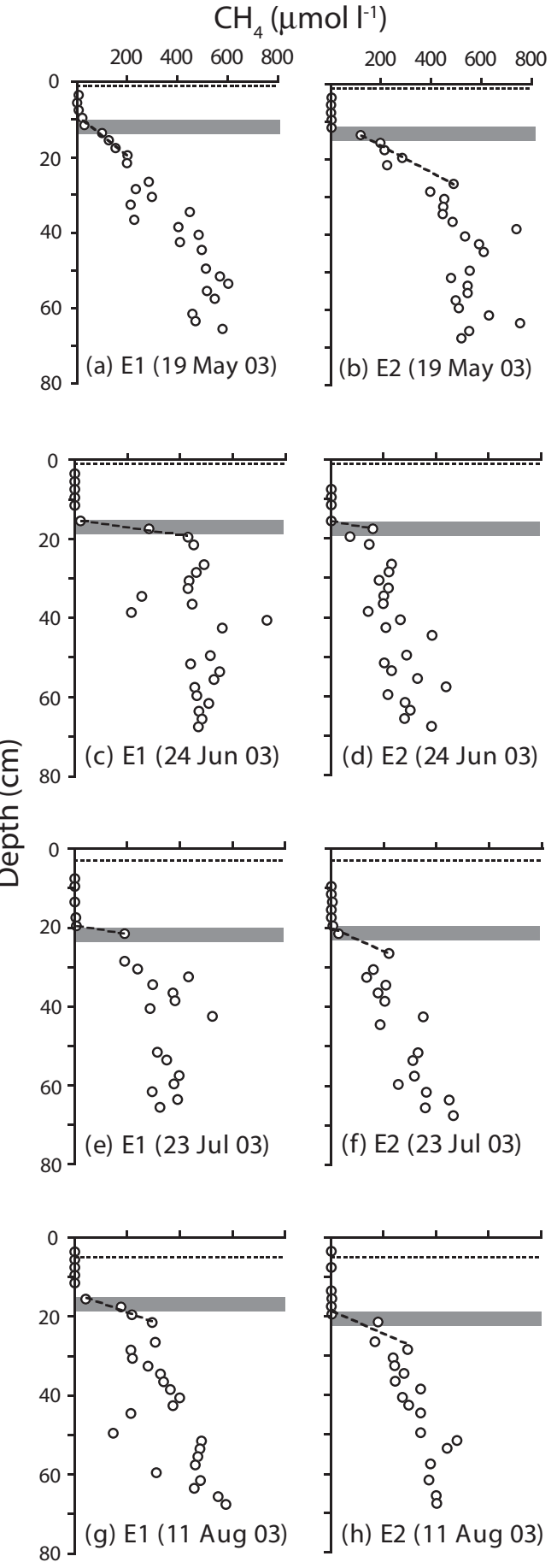

Fig. 4. Pore water profiles of dissolved $\mathrm{CH}_{4}$ measured at Gors Lwyd during the summer of 2003 from pore water equilibrators E1 and E2. Legend details are the same as described in the caption of Fig. 3.
$\mathrm{CH}_{4}\left(\mu \mathrm{mol} \mathrm{l}^{-1}\right)$
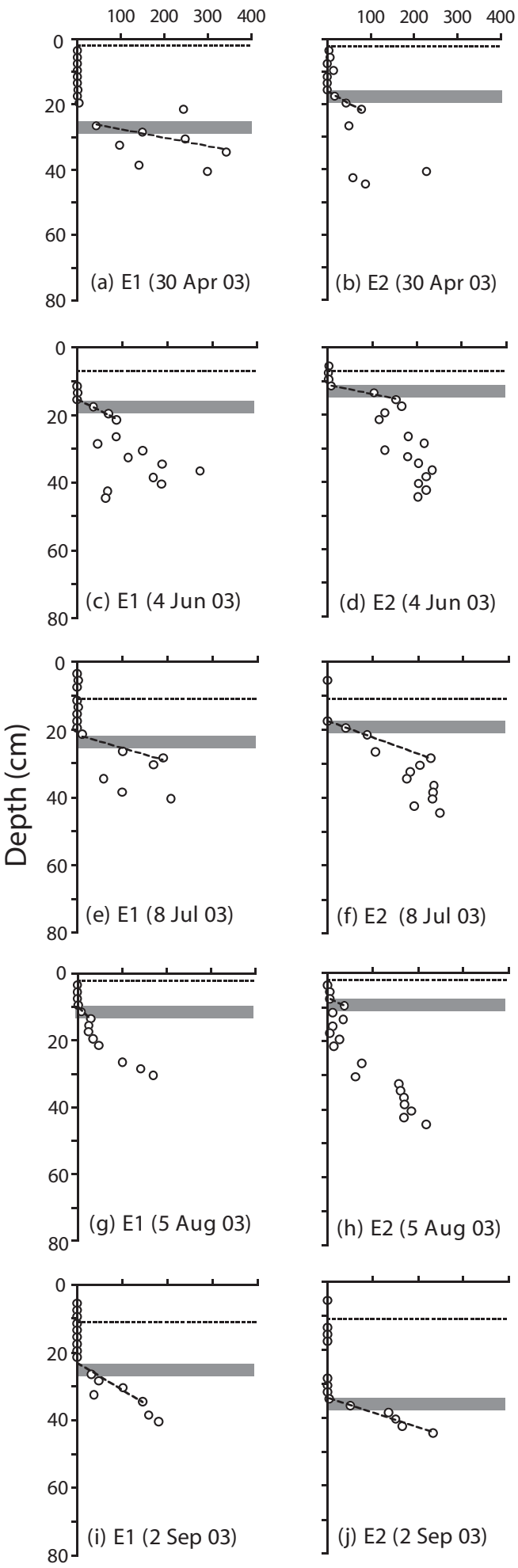

Fig. 5. Pore water profiles of dissolved $\mathrm{CH}_{4}$ measured at Blaen Fign during the summer of 2003 from pore water equilibrators E1 and E2. Legend details are the same as described in the caption of Fig. 3. 
$\left.\mathrm{CH}_{4}(\mu \mathrm{mol} \mathrm{I})^{-1}\right)$
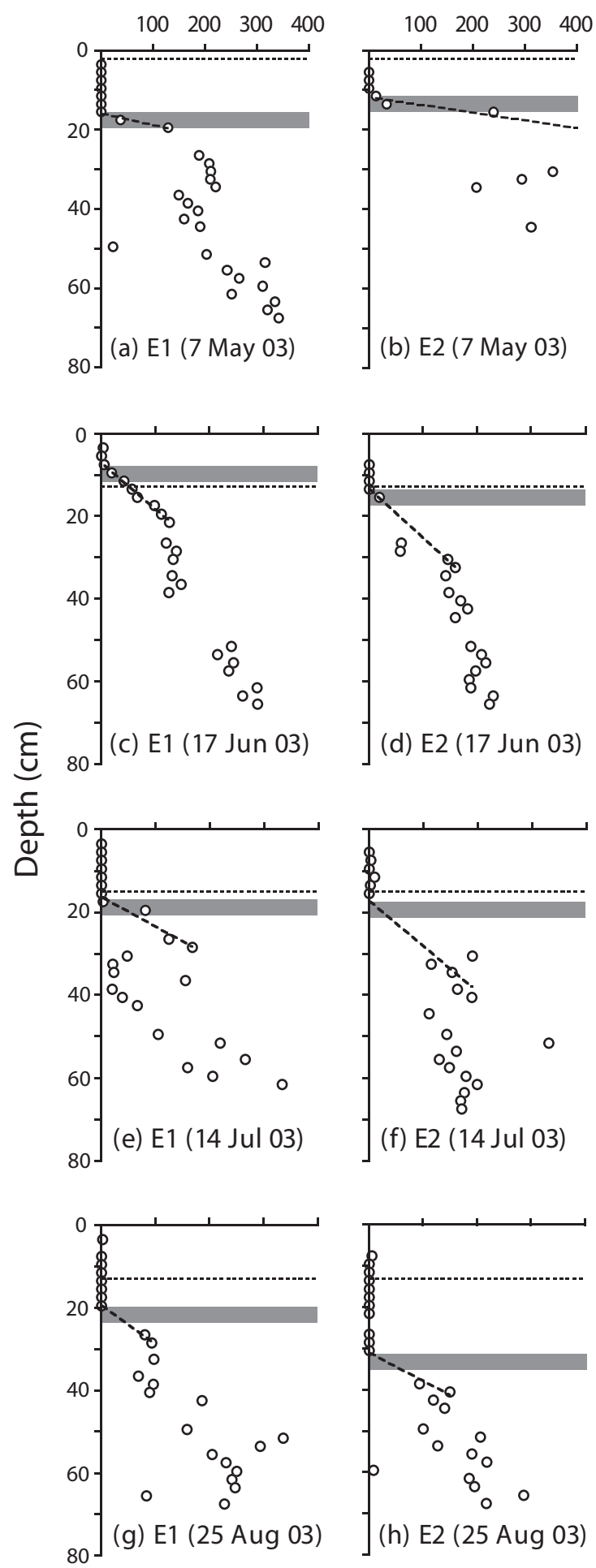

Fig. 6. Pore water profiles of dissolved $\mathrm{CH}_{4}$ measured at Cors Caron during the summer of 2003 from pore water equilibrators E1 and E2. Legend details are the same as described in the caption of Fig. 3. (i.e., ebullition) were excluded from the flux analysis because it could not be determined conclusively whether the events were natural or induced artifically during sample collection (see Table 3, footnote d).

In the minerotrophic peatlands (Crymlyn Bog and Gors Lwyd), $\mathrm{CH}_{4}$ emission rates to the atmosphere typically exceeded maximum rates of $\mathrm{CH}_{4}$ transport by pore water diffusion by one to two orders of magnitude, in particular, during summer months (Table 3). Fluxes of $\mathrm{CH}_{4}$ to the atmosphere were much smaller from the ombrotrophic peatlands (Blaen Fign and Cors Caron) with the exception of the sedge-rich plot (station 2) at Blaen Fign, consistent with the well known ability of many aquatic vascular plants to mediate gas transport via aerenchymatous tissue.

\section{Discussion}

\subsection{The influence of precipitation events on pore water $\mathrm{CH}_{4}$ profiles}

Rates of both aerobic and anaerobic microbial processes in peat soils can be affected by rainfall events through the introduction of electron acceptors such as $\mathrm{O}_{2}, \mathrm{SO}_{4}^{2-}$ and $\mathrm{NO}_{3}^{-}$ (Dise and Verry, 2001; Gauci et al., 2002; Gauci et al., 2004). Concentrations of microbial substrates in shallow peat layers, including dissolved gases (e.g., $\mathrm{CH}_{4}$ ), also may be influenced through dilution which may affect rates of processes such as methanogenesis and methanotrophy (Kettunen et al., 1996). Thus the timing of $\mathrm{CH}_{4}$ flux measurements or sampling of pore water $\mathrm{CH}_{4}$ concentrations should be considered when possible in relation to short-term precipitation events.

The distance between the water table level and depth where $\left[\mathrm{CH}_{4}\right]=0 \mu \mathrm{moll}^{-1}$ (i.e., $\left[\mathrm{CH}_{4}\right]_{0}$ ) differed greatly between the four peatland sites and sampling periods at individual sites (Figs. 3 to 6). The potential influence of precipitation input on this parameter was explored by comparing the depth to $\left[\mathrm{CH}_{4}\right]_{0}$ in the saturated zone with rainfall amounts on (i) the day of sampling, and (ii) the periods 1, 3, 5 and 7 days before sampling of pore water. Significant correlations existed with cumulative rainfall during the period 3 days prior to pore water sampling (Fig. 7 and Table 4) but not the amount of rainfall over shorter or longer periods before sample collection (data not shown; $r^{2}$ values typically $<0.40$ ). A few of the weaker correlations in Fig. 7 (e.g., Cors Caron, stations 1 and 2) result from single data points heavily skewing the linear regression analysis because of the small size of the data sets (i.e., typically $n=4$ ). Regression lines have a negative slope only for Crymlyn Bog, the most minerotrophic of the peatlands which receives significant moisture input from groundwater as well as precipitation. For the other three peatlands, including Gors Lwyd which is positioned at the head of a small catchment, the slopes of the regression equations are positive. The analysis in Table 4 and Fig. 7 suggests that in the absence of significant rainfall events, the depth of 
Table 4. Equations for linear regression curves in Fig. 7.

\begin{tabular}{lll}
\hline Site & Station 1 & Station 2 \\
\hline Crymlyn Bog & $\mathrm{y}=-0.41 \mathrm{x}+5.13\left(r^{2}=0.98 ; n=4\right)$ & $\mathrm{y}=-0.22 \mathrm{x}-2.95\left(r^{2}=0.29 ; n=3\right)$ \\
Gors Lwyd & $\mathrm{y}=0.86 \mathrm{x}+9.17\left(r^{2}=0.94 ; n=4\right)$ & $\mathrm{y}=0.68 \mathrm{x}+11.05\left(r^{2}=0.81 ; n=4\right)$ \\
Blaen Fign & $\mathrm{y}=0.74 \mathrm{x}+5.45\left(r^{2}=0.91 ; n=5\right)$ & $\mathrm{y}=0.62 \mathrm{x}+4.77\left(r^{2}=0.40 ; n=5\right)$ \\
Cors Caron & $\mathrm{y}=2.03 \mathrm{x}-0.29\left(r^{2}=0.61 ; n=4\right)^{\mathrm{a}}$ & $\mathrm{y}=0.71 \mathrm{x}+5.06\left(r^{2}=0.07 ; n=4\right)^{\mathrm{b}}$ \\
\hline
\end{tabular}

a Exclusion of 17 Jun 2003 data point yields $\mathrm{y}=1.61+3.01\left(r^{2}=0.84\right)$.

${ }^{\mathrm{b}}$ Exclusion of the $25 \mathrm{Aug} 2003$ data point yields $\mathrm{y}=1.61-1.29\left(r^{2}=0.99\right)$.

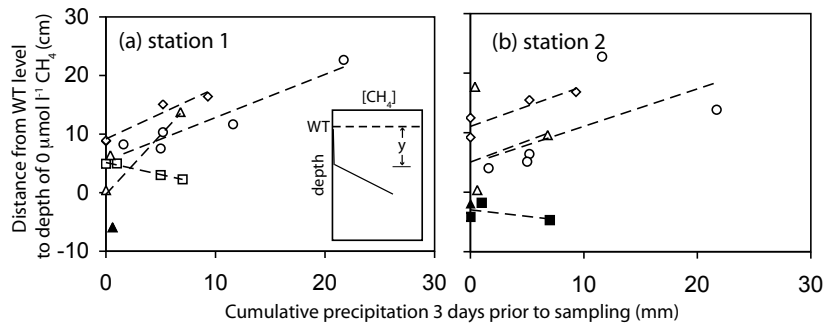

Fig. 7. Distance from water table surface to depth of nil $\mathrm{CH}_{4}$ concentration plotted against the cumulative amount of precipitation from the 3-day period prior to collection of the pore water $\mathrm{CH}_{4}$ samples. The y-axis parameter is explained graphically in the inset to panel (a). Y-axis data in panels (a) and (b) are from stations 1 and 2, respectively, at each peatland. The symbols correspond to Crymlyn Bog (squares), Cors Caron (triangles), Blaen Fign (circles), and Gors Lwyd (diamonds). Filled symbols represent times when $\left[\mathrm{CH}_{4}\right]$ was $>0 \mu \mathrm{moll}^{-1}$ at the air-water interface. Precipitation data (shown in Fig. 2) were taken from Swansea Victoria Park (src id 1257) for Crymlyn Bog, Swyddffynnon (src id 1204) for Cors Caron, and Cwmystwyth (src id 1211) for Blaen Fign and Gors Lwyd. The dashed lines are linear regression analysis curves fitted to the data for each peatland. The equations for the eight regression lines are listed in Table 4.

$\left[\mathrm{CH}_{4}\right]_{0}$ is not as variable as implied in Figs. 3 to 6 . The large range of values for this parameter likely reflect differences in recent input of precipitation rather than microbiological driven changes in methane production and consumption. The "normal" depth of $\left[\mathrm{CH}_{4}\right]_{0}$ appears to vary between individual peatlands as indicated by differences in the y-intercepts of the regression equations in Table 4 (e.g., $\sim 10 \mathrm{~cm}$ for Gors Lwyd versus $\sim 5 \mathrm{~cm}$ for Blaen Fign).

Noteworthy in Fig. 7 are the infilled data points for Cors Caron and Crymlyn Bog that lie largely at $\mathrm{x}$-values of $\sim 0 \mathrm{~mm}$ (i.e., when little or no rainfall occurred prior to the sampling period). The infilled points (5 in total) represent times when the concentration of dissolved $\mathrm{CH}_{4}$ at the water table level exceeded $0 \mu \mathrm{moll}^{-1}$ and $\mathrm{CH}_{4}$ transport was occurring across the subsurface air-water interface. The correlations in Table 4 will be unimportant during periods of low rainfall and at those times $\mathrm{CH}_{4}$ most likely is able to diffuse across the water table surface because heterotrophic activity in the unsaturated zone has depleted $\mathrm{O}_{2}$ from pore spaces.

\section{$5.2 \mathrm{CH}_{4}$ oxidation kinetics}

The $\mu_{m}$ values determined for different depth intervals at Crymlyn Bog and Cors Caron (Table 3; $S_{0}=10$ to $100 \mu \mathrm{moll}^{-1}$ values) lie within the range of potential methane oxidation rates $\left(0.1\right.$ to $\left.100 \mu \mathrm{mol} \mathrm{m}^{-3} \mathrm{~s}^{-1}\right)$ compiled by Segers (1998) for different types of environments that host low affinity methanotrophic activity. Conversion of units in Table 3 for comparison yield $\mu_{m}$ values of 0.5 to 1.1 and 2.9 to $5.9 \mu \mathrm{mol} \mathrm{m}^{-3} \mathrm{~s}^{-1}$, respectively, for Crymlyn Bog and Cors Caron. Half saturation constants for Cors Caron also are higher than values for Crymlyn Bog. It is unclear why methanotrophs in the raised bog environment should have a lower affinity for substrate (i.e., higher $K_{S}$ ) and molecular biology data are unavailable to determine whether differences existed in methanotrophy communities at the two peatlands. Athough the two peatlands differ in the composition and $\mathrm{pH}$ of their soil solution, we cannot speculate about potential relationships between the parameters $\mu_{m}$ and $K_{s}$, and factors such as $\mathrm{pH}$ because slurries were diluted 1:1 with deionized water. The buffering capacity of peat from the two sites would have differed considerably (i.e., rainfed versus groundwater influenced). However, $K_{s}$ values cited by Segers (1997) for peat soil ranged from 1 to $45 \mu \mathrm{moll}^{-1}$, encompassing the values determined for Crymlyn Bog. Watson et al. (1997) reported a $K_{s}$ of $57.9 \mu \mathrm{moll}^{-1}$ for $\mathrm{CH}_{4}$ oxidation in acidic peat from Ellergower Moss, comparable to the range of half saturation constants determined with depth for Cors Caron, which also is a raised bog (i.e., 42.6 to $68.1 \mu \mathrm{moll}^{-1}$; Table 3).

The range of $\mu_{m}$ and $K_{s}$ values in Table 3 is noteworthy also because of the difficulties such variability presents in efforts to model $\mathrm{CH}_{4}$ dynamics in peatland soils. For example, one of the more rigorous process-based models for estimating $\mathrm{CH}_{4}$ flux from peatlands (Walter and Heimann, 2000) employs the assumption that the parameters $\mu_{m}$ and $K_{s}$ for methanotrophy are constant with depth and in different types of wetlands, assigning values of $20 \mu \mathrm{moll}^{-1} \mathrm{~h}^{-1}$ and $5 \mu \mathrm{moll}^{-1}$, respectively. The mean $\mu_{m}$ values for Crymlyn 
Bog and Cor Caron suggest that maximum rates of $\mathrm{CH}_{4}$ oxidation may differ between minerotrophic and ombrogenous mires and in both cases appear to decrease gradually with depth. As noted previously, half saturation concentrations also may be higher in acidic rainfed peatlands (e.g., Table 3 and Watson et al., 1997). Availability of kinetic parameters describing $\mathrm{CH}_{4}$ oxidation in peatlands is too limited at present to attempt to develop generalised relationships describing $\mu_{m}$ and $K_{s}$ in different types of peatlands and spatially and temporally within individual sites.

\subsection{Methane supply, demand and net flux}

The amount of upward $\mathrm{CH}_{4}$ transport in all four peatlands via pore water diffusion typically was $<10 \mathrm{mg} \mathrm{m}^{-2} \mathrm{~d}^{-1}$ and exceeded this value in only 4 of the 33 pore water $\mathrm{CH}_{4}$ profiles collected during the summer of 2003. Rates of $\mathrm{CH}_{4}$ emission to the atmosphere from Blaen Fign and Cors Caron were the same order of magnitude as pore water $\mathrm{CH}_{4}$ diffusion rates; however, it is unlikely that $\mathrm{CH}_{4}$ transport by this mode contributed to atmospheric flux. The stable carbon isotope compositions ( $\left({ }^{13} \mathrm{C}\right.$ values) of $\mathrm{CH}_{4}$ in pore water and surface flux have been used previously to demonstrate that diffusive emission of $\mathrm{CH}_{4}$ to the atmosphere at all four peatlands occurs predominately via plant-mediated transport (Bowes and Hornibrook, 2006; Hornibrook and Bowes, 2007). For example, $\mathrm{CH}_{4}$ emitted at a higher rate from sedge-rich station 2 at Blaen Fign has $\delta^{13} \mathrm{C}$ values that are statistically indistinguishable from $\mathrm{CH}_{4}$ emissions from Sphagnum-rich station 1 (Bowes and Hornibrook, 2006). The $\delta^{13} \mathrm{C}$ composition of $\mathrm{CH}_{4}$ emissions from both plots are ${ }^{13} \mathrm{C}$-depleted by $\sim 15$ to 20\% relative to pore water $\mathrm{CH}_{4}$, which eliminates the possibility that the small quantities of $\mathrm{CH}_{4}$ emitted from station 1 are residual $\mathrm{CH}_{4}$ that has survived transit across the unsaturated zone (Happell et al., 1994; Popp et al., 1999). Similarly, $\mathrm{CH}_{4}$ emissions from Cors Caron, Crymlyn Bog and Gors Lwyd also are ${ }^{13} \mathrm{C}$-depleted relative to the pore water $\mathrm{CH}_{4}$ pool (Hornibrook and Bowes, 2007). These conclusions about transport processes based upon stable isotope data are consistent with the observation reported here that low affinity methanotrophs in the $3 \mathrm{~cm}$ thick zone where $\mathrm{CH}_{4}$ first appears in the pore water pool (i.e., immediately below the depth $\left[\mathrm{CH}_{4}\right]_{0}$ ) have a capacity for $\mathrm{CH}_{4}$ consumption that significantly exceeds the upward $\mathrm{CH}_{4}$ supply via pore water diffusion (Table 3 ). While low affinity methanotrophs appear to consume the bulk of $\mathrm{CH}_{4}$ transported along concentration gradients in pore water, they do not provide a robust barrier to $\mathrm{CH}_{4}$ flux from peatlands because of the prevalence of $\mathrm{CH}_{4}$ movement through vascular plants which bypasses the methanotrophy filter. During June to August, microbial $\mathrm{CH}_{4}$ oxidation rates ranged from 0.8 to $40.7 \%$ of total $\mathrm{CH}_{4}$ flux to the atmosphere in Crymlyn Bog and Gors Lwyd; however, the majority of values were $<10 \%$. In the same months, the percentages were higher at sedge-poor plots at the ombrotrophic mires (Blaen Fign, 9.3 to 53.4\%; Cors Caron,
11.0 to $21.1 \%$ ), but the difference in proportions is unimportant because as indicated by $\delta^{13} \mathrm{C}$ data little or none of the diffusion transported $\mathrm{CH}_{4}$ contributed to surficial emissions (Hornibrook and Bowes, 2007). Consequently, in the absence of bacterial $\mathrm{CH}_{4}$ oxidation the $\mathrm{CH}_{4}$ flux rate from minerotrophic peatlands would not be significantly greater in absolute terms but the increase would be proportionally much larger from the ombrotrophic bogs. The steady state flux rates of $>100 \mathrm{mg} \mathrm{CH}_{4} \mathrm{~m}^{-2} \mathrm{~d}^{-1}$ commonly observed from wetland soils (e.g., Whalen, 2005) would be difficult to achieve if pore water diffusion alone was the dominant transport mechanism. The bulk of $\mathrm{CH}_{4}$ emitted from peatlands typically occurs via vascular plants and possibly ebullition, although data for the latter transport process remain sparse (Baird et al., 2004).

\section{Conclusions}

The depth below ambient water table levels at which dissolved methane is depleted to $\sim 0 \mu \mathrm{moll}^{-1}$ by methanotrophic activity varies widely between peatlands and temporally within individual peatlands. Short-term precipitation events appear to increase the depth to $\left[\mathrm{CH}_{4}\right]_{0}$ without necessarily disturbing dissolved $\mathrm{CH}_{4}$ profiles. In the absence of recent rainfall input, the depth of $\left[\mathrm{CH}_{4}\right]_{0}$ below the water table level ranged from $\sim 5$ to $10 \mathrm{~cm}$, although the size of the interval diminished to 0 (i.e., $\mathrm{CH}_{4}$ present at the water table surface) during prolonged periods without precipitation input.

The capacity for methanotrophy in peatland soils from both minerotrophic and ombrotrophic peatlands typically was greater than the available supply of upward diffusing $\mathrm{CH}_{4}$. Kinetic parameters $\left(\mu_{m}\right.$ and $\left.K_{s}\right)$ describing the response of methanotroph populations to substrate (i.e., $\mathrm{CH}_{4}$ ) concentrations are not constant with depth as assumed in some process models and both parameters were larger in the ombrotrophic versus minerotrophic peatlands. Low affinity methanotrophic activity effectively consumes the majority of upward diffusing $\mathrm{CH}_{4}$ in peatland soil (in most cases $100 \%$ ). Maximum rates of $\mathrm{CH}_{4}$ flux by pore water diffusion were at most 10 to $20 \mathrm{mg} \mathrm{m}^{-2} \mathrm{~d}^{-1}$, which in minerotrophic mires represents typically $<10 \%$ of actual emissions. The generally lower $\mathrm{CH}_{4}$ emission rates from ombrotrophic mires would be impacted more by cessation or attentuation of methanotrophy activity but diffusive $\mathrm{CH}_{4}$ flux rates would still amount to only a few $10 \mathrm{~s}$ of $\mathrm{mg} \mathrm{m}^{-2} \mathrm{~d}^{-1}$.

Acknowledgements. We thank Mike Dury for manufacturing flux chambers and pore water equilibrators. HLB was supported by an NERC postgraduate scholarship and AVGS by a NERC Industrial CASE scholarship. This study was funded by NERC (NER/B/S/2000/00076) and Royal Society (574006.G503/21832/SM) grants to ERCH. The UK Joint Higher Education Funding Council for England and Office of Science and Technology Science Research Investment Fund (SRIF), and the 
University of Bristol are thanked for infrastructure funding. We thank the British Atmospheric Data Centre (BADC) for technical advice and permission to use daily precipitation data from Met Office weather stations in Wales.

Edited by: C. Slomp

\section{References}

Baird, A. J., Beckwith, C. W., Waldron, S., and Waddington, J. M.: Ebullition of methane-containing gas bubbles from near-surface sphagnum peat, Geophys. Res. Lett., 31, L21505, doi:10.1029/2004GL021157, 2004.

Basiliko, N., Blodau, C., Roehm, C., Bengtson, P., and Moore, T. R.: Regulation of decomposition and methane dynamics across natural, commercially mined, and restored northern peatlands, Ecosystems, 10, 1148-1165, 2007.

Beckmann, M. and Lloyd, D.: Mass spectrometric monitoring of gases $\left(\mathrm{CO}_{2}, \mathrm{CH}_{4}, \mathrm{O}_{2}\right)$ in a mesotrophic peat core from Kopparas Mire, Sweden, Global Change Biol., 7, 171-180, 2001.

Berestovskaya, Y. Y., Rusanov, II, Vasil'eva, L. V., and Pimenov, N. V.: The processes of methane production and oxidation in the soils of the Russian arctic tundra, Microbiology, 74, 221-229, 2005.

Boon, P. I. and Lee, K.: Methane oxidation in sediments of a floodplain wetland in south-eastern australia, Lett. Appl. Microbiol., 25, 138-142, 1997.

Bowes, H. L. and Hornibrook, E. R. C.: Emision of highly ${ }^{13}$ Cdepleted methane from an upland blanket mire, Geophys. Res. Lett., 33, L04401, doi:10.1029/2005GL025209, 2006.

Calhoun, A. and King, G. M.: Characterization of root-associated methanotrophs from three freshwater macrophytes: Pontederia cordata, Sparganium eurycarpum, and Sagittaria latifolia, Appl. Environ. Microbiol., 64, 1099-1105, 1998.

Chen, Y., Dumont, M. G., McNamara, N. P., Chamberlain, P. M., Bodrossy, L., Stralis-Pavese, N., and Murrell, J. C.: Diversity of the active methanotrophic community in acidic peatlands as assessed by mRNA and SIP-PLFA analyses, Environ. Microbiol., 10, 446-459, 2008.

Dedysh, S. N.: Methanotrophic bacteria of acidic sphagnum peat bogs, Microbiology, 71, 638-650, 2002.

Dedysh, S. N., Derakshani, M., and Liesack, W.: Detection and enumeration of methanotrophs in acidic sphagnum peat by $16 \mathrm{~s}$ rRNA fluorescence in situ hybridization, including the use of newly developed oligonucleotide probes for Methylocella palustris, Appl. Environ. Microbiol., 67, 4850-4857, 2001.

Dedysh, S. N., Dunfield, P. F., Derakshani, M., Stubner, S., Heyer, J., and Liesack, W.: Differential detection of type II methanotrophic bacteria in acidic peatlands using newly developed $16 \mathrm{~s}$ rRNA-targeted fluorescent oligonucleotide probes, FEMS Microbiology Ecology, 43, 299-308, 2003.

Dise, N. B. and Verry, E. S.: Suppression of peatland methane emission by cumulative sulfate deposition in simulated acid rain, Biogeochemistry, 53, 143-160, 2001.

Edwards, C., Hales, B. A., Hall, G. H., McDonald, I. R., Murrell, J. C., Pickup, R., Ritchie, D. A., Saunders, J. R., Simon, B. M., and Upton, M.: Microbiological processes in the terrestrial carbon cycle: Methane cycling in peat, Atmos. Environ., 32, 3247-3255, 1998.
Gauci, V., Dise, N., and Fowler, D.: Controls on suppression of methane flux from a peat bog subjected to simulated acid rain sulfate deposition, Global Biogeochem. Cy., 16, doi:10.1029/2000GB001370, 1004, 2002.

Gauci, V., Matthews, E., Dise, N., Walter, B., Koch, D., Granberg, G., and Vile, M.: Sulfur pollution suppression of the wetland methane source in the 20th and 21st centuries, Proceedings of the National Academy of Sciences of the United States of America, 101, 12583-12587, 2004.

Gutknecht, J. L. M.: Linking soil process and microbial ecology in freshwater wetland ecosystems, Plant Soil, 289, 17-34, 2006.

Happell, J. D., Chanton, J. P., and Showers, W. S.: The influence of methane oxidation on the stable isotopic composition of methane emitted from florida swamp forests, Geochimica et Cosmochimica Acta, 58, 4377-4388, 1994.

Hesslein, R. H.: An in situ sampler for close interval pore water studies, Limnol. Oceanogr., 912-914, 1976.

Hornibrook, E. R. C. and Bowes, H. L.: Trophic status impacts both the magnitude and stable carbon isotope composition of methane flux from peatlands, Geophys. Res. Lett., 34, L21401, doi:10.1029/2007GL031231, 2007.

Joabsson, A. and Christensen, T. R.: Methane emissions from wetlands and their relationship with vascular plants: An arctic example, Global Change Biol., 7, 919-932, 2001.

Joabsson, A., Christensen, T. R., and Wallen, B.: Vascular plant controls on methane emissions from northern peatforming wetlands, Trends Ecol. Evol., 14, 385-388, 1999.

Kettunen, A.: Connecting methane fluxes to vegetation cover and water table fluctuations at microsite level: A modeling study, Global Biogeochem. Cy., 17, 1051, doi:10.1029/2002GB001958, 2003.

Kettunen, A., Kaitala, V., Alm, J., Silvola, J., Nykanen, H., and Martikainen, P. J.: Cross-correlation analysis of the dynamics of methane emissions from a boreal peatland, Global Biogeochem. Cy., 10, 457-471, 1996.

Kettunen, A., Kaitala, V., Lehtinen, A., Lohila, A., Alm, J., Silvola, J., and Martikainen, P. J.: Methane production and oxidation potentials in relation to water table fluctuations in two boreal mires, Soil Biol. Biochem., 31, 1741-1749, 1999.

King, G. M.: Dynamics and controls of methane oxidation in a danish wetland sediment, FEMS Microbiology Ecology, 74, 309323, 1990.

King, G. M.: Associations of methanotrophs with the roots and rhizomes of aquatic vegetation, Appl. Environ. Microbiol., 60, 3220-3227, 1994.

King, G. M.: In situ analyses of methane oxidation associated with the roots and rhizomes of a bur reed, sparganium eurycarpum, in a maine wetland, Appl. Environ. Microbiol., 62, 4548-4555, 1996.

Kreuzer-Martin, H. W.: Stable isotope probing: Linking functional activity to specific members of microbial communities, Soil Sci. Soc. Am. J., 71, 611-619, 2007.

Krumholz, L. R., Hollenback, J. L., Roskes, S. J., and Ringelberg, D. B.: Methanogenesis and methanotrophy within a sphagnum peatland, FEMS Microbiology Ecology, 18, 215-224, 1995.

Le Mer, J. and Roger, P.: Production, oxidation, emission and consumption of methane by soils: A review, European Journal of Soil Biology, 37, 25-50, 2001.

Lerman, A.: Geochemical processes: Water and sediment environ- 
ments, John Wiley \& Sons, New York, USA, 481 pp., 1979.

McAullife, C.: GC determination of solutes by multiple phase equilibration, Chem. Technol., 1, 46-51, 1971.

McDonald, I. R., Hall, G. H., Pickup, R. W., and Murrell, J. C.: Methane oxidation potential and preliminary analysis of methanotrophs in blanket bog peat using molecular ecology techniques, FEMS Microbiology Ecology, 21, 197-211, 1996.

McDonald, I. R., Upton, M., Hall, G., Pickup, R. W., Edwards, C., Saunders, J. R., Ritchie, D. A., and Murrell, J. C.: Molecular ecological analysis of methanogens and methanotrophs in blanket bog peat, Microbiol. Ecol., 38, 225-233, 1999.

McDonald, I. R., Radajewski, S., and Murrell, J. C.: Stable isotope probing of nucleic acids in methanotrophs and methylotrophs: A review, Organic Geochem., 36, 779-787, 2005.

Megonigal, J. P. and Schlesinger, W. H.: Methane-limited methanotrophy in tidal freshwater swamps, Global Biogeochem. Cy., 16, 1088, doi:10.1029/2001GB001594, 2002.

Mikaloff Fletcher, S. E., Tans, P. P., Bruhwiler, L. M., Miller, J. B., and Heimann, M.: $\mathrm{CH}_{4}$ sources estimated from atmospheric observations of $\mathrm{CH}_{4}$ and its ${ }^{13} \mathrm{C} /{ }^{12} \mathrm{C}$ isotopic ratios: 2. Inverse modeling of $\mathrm{CH}_{4}$ fluxes from geographical regions, Global Biogeochem. Cy., 18, GB4005, doi:10.1029/2004GB002224, 2004.

Mikkelä, C., Sundh, I., Svensson, B. H., and Nilsson, M.: Diurnal variation in methane emission in relation to the water-table, soil temperature, climate and vegetation cover in a swedish acid mire, Biogeochemistry, 28, 93-114, 1995.

Miller, D. N., Yavitt, J. B., Madsen, E. L., and Ghiorse, W. C.: Methanotrophic activity, abundance, and diversity in forested swamp pools: Spatiotemporal dynamics and influences on methane fluxes, Geomicrobiol. J., 21, 257-271, 2004.

Morris, S. A., Radajewski, S., Willison, T. W., and Murrell, J. C.: Identification of the functionally active methanotroph population in a peat soil microcosm by stable-isotope probing, Appl. Environ. Microbiol., 68, 1446-1453, 2002.

Oquist, M. G. and Svensson, B. H.: Vascular plants as regulators of methane emissions from a subarctic mire ecosystem, J. Geophys. Res.-Atmos., 107, 4580, doi:10.1029/2001JD001030, 2002.

Pearce, D. M. E. and Clymo, R. S.: Methane oxidation in a peatland core, Global Biogeochem. Cy., 15, 709-720, 2001.

Popp, T. J., Chanton, J. P., Whiting, G. J., and Grant, N.: Methane stable isotope distribution at a carex dominated fen in north central alberta, Global Biogeochem. Cy., 13, 1063-1077, 1999.

Popp, T. J., Chanton, J. P., Whiting, G. J., and Grant, N.: Evaluation of methane oxidation in the rhizosphere of a carex dominated fen in north central alberta, canada, Biogeochemistry, 51, 259-281, 2000.

Ritchie, D. A., Edwards, C., McDonald, I. R., and Murrell, J. C.: Detection of methanogens and methanotrophs in natural environments, Global Change Biol., 3, 339-350, 1997.

Roslev, P. and King, G. M.: Regulation of methane oxidation in a freshwater wetland by water table changes and anoxia, FEMS Microbiology Ecology, 19, 105-115, 1996.

Roulet, N. T., Ash, R., Quinton, W., and Moore, T.: Methane flux from drained northern peatlands: Effect of a persistent water table lowering on flux, Global Biogeochem. Cy., 7, 749-769, 1993.
Schipper, L. A. and Reddy, K. R.: Determination of methane oxidation in the rhizosphere of Sagittaria lancifolia using methyl fluoride, Soil Sci. Soc. Am. J., 60, 611-616, 1996.

Segers, R.: Methane production and methane consumption: A review of processes underlying wetland methane fluxes, Biogeochemistry, 41, 23-51, 1998.

Shannon, R. D., White, J. R., Lawson, J. E., and Gilmour, B. S.: Methane efflux from emergent vegetation in peatlands, Journal of Ecology, 84, 239-246, 1996.

Ström, L. and Christensen, T. R.: Below ground carbon turnover and greenhouse gas exchanges in a sub-arctic wetland, Soil Biol. Biochem., 39, 1689-1698, 2007.

Ström, L., Mastepanov, M., and Christensen, T. R.: Species-specific effects of vascular plants on carbon turnover and methane emissions from wetlands, Biogeochemistry, 75, 65-82, 2005.

Sundh, I., Nilsson, M., Granberg, G., and Svensson, B. H.: Depth distribution of microbial production and oxidation of methane in northern boreal peatlands, Microbial Ecol., 27, 253-265, 1994.

Sundh, I., Borga, P., Nilsson, M., and Svensson, B. H.: Estimation of cell numbers of methanotrophic bacteria in boreal peatlands based on analysis of specific phospholipid fatty acids, FEMS Microbiology Ecology, 18, 103-112, 1995.

Sundh, I., Nilsson, M., and Borga, P.: Variation in microbial community structure in two boreal peatlands as determined by analysis of phospholipid fatty acid profiles, Appl. Environ. Microbiol., 63, 1476-1482, 1997.

Tokida, T., Miyazaki, T., Mizoguchi, M., Nagata, O., Takakai, F., Kagemoto, A., and Hatano, R.: Falling atmospheric pressure as a trigger for methane ebullition from peatland, Global Biogeochem. Cy., 21, GB2003, doi:10.1029/2006GB002790, 2007a.

Tokida, T., Mizoguchi, M., Miyazaki, T., Kagemoto, A., Nagata, O., and Hatano, R.: Episodic release of methane bubbles from peatland during spring thaw, Chemosphere, 70, 165-171, $2007 \mathrm{~b}$.

van der Nat, F. J. W. A. and Middelburg, J. J.: Seasonal variation in methane oxidation by the rhizosphere of phragmites australis and scirpus lacustris, Aquat. Botany, 61, 95-110, 1998.

Walter, B. P., Heimann, M., and Matthews, E.: Modeling modern methane emissions from natural wetlands 1 . Model description and results, J. Geophys. Res.-Atmos., 106, 34189-34206, 2001.

Wartiainen, I., Hestnes, A. G., and Svenning, M. M.: Methanotrophic diversity in high arctic wetlands on the islands of Svalbard (Norway) - denaturing gradient gel electrophoresis analysis of soil DNA and enrichment cultures, Canad. J. Microbiol., 49, 602-612, 2003.

Watson, A., Stephen, K. D., Nedwell, D. B., and Arah, J. R. M.: Oxidation of methane in peat: Kinetics of $\mathrm{CH}_{4}$ and $\mathrm{O}_{2}$ removal and the role of plant roots, Soil Biol. Biochem., 29, 1257-1267, 1997.

Whalen, S. C.: Biogeochemistry of methane exchange between natural wetlands and the atmosphere, Environ. Eng. Sci., 22, 73-94, 2005.

Whalen, S. C. and Reeburgh, W. S.: Methane oxidation, production, and emission at contrasting sites in a boreal bog, Geomicrobiol. J., 17, 237-251, 2000. 